\title{
An Assessment of Agric ultural Freight Transportation in Saki Area of Oyo State, Nigeria
}

\author{
Simeon Oluwa gbenga FASINA ${ }^{1}$, Ayobami Ademola AKANMU², Adesoji O. ADESANYA ${ }^{3}$, a nd \\ Umar Obafemi SAUSU1* \\ ${ }^{1}$ Ola bisi Onabanjo University/Department of Urban and Regional Planning, Ago-Iwoye, Nigeria \\ 2The Oke-Ogun Polytechnic/Department of Urban and Regional Planning, Saki, Nigeria. \\ ${ }^{3}$ Nigerian Institute of Social and Ec onomic Research/Polic y Engagement Division, Iba dan, Nigeria
}

Corresponding Author indic ated by an asterisk*

\begin{abstract}
Transportation no doubt remains a catalyst for all aspect of socio-economic and environmental development Without its singular significance of mobility and accessibility for farmers, agricultural produce will roton fams, while efforts in providing food would be fruitless. This paperassessed agnicultural freight transportation in Saki area of Oyo State with a view of enhancing better product delivery mechanisms for farmers. It examined farmers' socio-demographic; nature of faming and fam charactenistics; and appraised the relationship between attributes of agric ultural production and freight movement. Primary data employed consists of a questionnaire designed forfamers, structured intenview forgovemment offic ials complemented with personal field obsenations of agricultural freighttransportation. 225 famers were randomly selected forquestionnaire administration. Major findings revealed that food crops, vegetables, fruits and poultry products are in persistent motion in the study area and that agricultural freight is a neglected sector with significant consequences on the access to cheap and affordable urban wellbeing. Findings also revealed that agricultural freight transportation within the study is very poor and uneconomical, as this depletes famers' profit-making. Regression analysis results show a significant relationship between attributes of agricultural freight and transport cost $\left(F^{10}{ }_{205} \quad 11.916=P<0.05\right)$. The study recommends extensive road rehabilitation and constructions within the study area; provision of technological driven distribution and storage infrastructural facilities; creation of a databank for agricultural freighttransport, reorganization and empowement of famers and improvement of rural infrastructure in Oyo state and Nigeria as a whole.
\end{abstract}

Index Terms - Farmers, Agric ultural Freight, Transportation, Saki Area

\section{INTRODUCTION}

Agriculture, no doubt remains a backbone of many nations socio-economic, political and environmental development since time immemorial. Even, the early development of Nigeria economy and her colonization by British were partial as a result of her favourable agricultural potentials and supporting climatic conditions. It is on this basis that $[4,12,19,20]$ opined that agriculture sustained Nigerian economy at independence with the promise of a vibrant agrarian ec onomy by contributing 67 per cent of the Gross Domestic Product (GDP) in 1960/61. However, [23, 24] opines that the contribution of agric ultural sector to total GDP of Nigeria has fallen over the decades, from a very dominant position of 55.8 percent of the GDP in 1960-1970 to 28.4 per cent in 1971-1980, before rising to 32.3, 34.2 and 40.3 per cent during the decades 1981-1990, 1991-2000 and 2001-2009 respec tively.

Transportation in one form or the other is a basic and essential requirement of daily human ac tivities a sno human a c tivities (including a gric ulture) can ta ke place without its servic es [2, 21]. While freight transportation plays a crucial role in the smooth running of any economy in which road sector dominates, agric ultural practices usually produce freight which in tums translates into wealth for the national economy including developed and developing ones [18, 21]. Agricultural freight comprises of agricultural produce from the famlands to non-urbanised areas, markets, city centres and for exports to other countries $[5,6]$.

Such freight consists of food crops, cash crops, livestock, poultry products a nd perishables such as vegetables, tomatoes, pepper and fruits etc., that are produced majorly in rural settlements at 
different scales [6, 18, 20], and for towns and cities whic $h$ constitute the best-price market for such. In this regard, urban inhabitants across the world depend on farmers in agricultural a reas for their daily requirements of agricultural goods for consumption, industrial processes and other production activities [20, 25]. Hence, the need for an efficient flow of agricultural produce from agricultural communities to urban centres as a fundamental aspect of the daily functioning of the urban-rural system towards the sustenance of human popula tion must not be compromised.

The rea lity of transp ort especia lly in a gric ultural producing a reas such as Sa ki is that a considera ble a mount of valuable time, efforts and incommensurate a mount of money a re required to access this socio-economic service. Majority of communities in Saki area a re not only rural but depend on rural road transport for personal mobility and marketing of their resource-based production. However, the profitability of farming operations is affected particularly when prices of the produce adjust to changes in transportation rates. Regrettably, limited or no attention is being accorded to a gric ultural freight and more importantly efficient flow and movement of traffic (freight). Therefore, attempts to bridge such gap and the need to facilitate timely, cheap and easy delivery of a gricultural freight to boost the productive capacity of famers within Oyo State and Nigeria at la rge necessita ted scholars cum professiona Is' intervention partic ula rly through researc $\mathrm{h}$ recommendations.

More so, despite knowing Saki area as the food-basket of Oyo State, road transportation system partic ula rly freight transporta tion is usually fraught with serious challenges whic $h$ usually reflected and resulted to high transport cost of agricultural freight to prospective diverse destinations; increasing crime rate; theft; road crashes and freight damages. Furthemore, with the global food crisis occasioned by climate change, the need to enhance fast technological d riven evacuation measures through smart distribution and supply methods of agricultural produce and general freight to consuming places is of utmost necessary particularly in developing nations including Nigeria. It is based on these foregoing that this paper analyses agricultural freight transportation from the perspectives of famers, and equally bridge the academic gap with better measures and recommendations to facilitates timely and smart freight delivery mechanisms and production capacity of farmers within the study area and areas with similar characteristics and challenges in Nigeria and its environs. In achieving this aim, specific objectives pursued were to examine the socioeconomic characteristics of famers in the study area, assess the nature of farming and farm characteristic s in the study a rea, appraise the characterization of a gric ultural production and freight transportation as well as establish the statistical relationship between the attributes of agricultural freight and transport cost. In other words, for logical and factual understanding, this study was structured into five sections. Following the introductory section was the brief literature review. The third section dealt with the study methodology. It gave an insight into the study area and sampling collection methods. The fourth section presents the a nalyzed data and disc ussion of findings, while the fifth and the last concludes with the way forward.

\section{BRIEF UTERATURE REVIEW}

Transport is not an end in itself, it represents a n engine and catalyst for not only socio-economic s development but the survival and susta inability of both national a nd intema tional economies [22]. The effective and safe exchange of resources (human and non-human), materials, information and services constitute the principal function of a ny transport system including freight transport $[8,22)$. By definition, agric ultural freight transportation involves the movement or conveyance of agricultural products from the famlands to the domestic markets and outwards as export to a nother country or across the border. Meanwhile, [11] observed that agric ultural product freight movement is one of the largest consumers of freight transportation services in the United States of Americ a and the growth in a gric ulture cultivation during the last decades is prima rily indebted to the transportation system.

The ma in objective of agricultural freight transportation is to meet the ever-increasing demand and supply of agricultural produce with minimum expenditure of resources without compromising both time and place utilities. Thus, through effic ient delivery of raw materia Is a nd finished goodstimely, cheaply and safely, formidable and sound economic performance is guaranteed. Moreover, studies like $[16,8,13,26,3,14,15]$ have studied and revealed the importance of freight transportation to the human and natural environment as well as national growth and economic development. 
Unfortunately, despite this notic eable importance as revealed in literature, the agricultural freight tra nsportation, partic ula rly in the third world countries including Nigeria, is still faced with different issues including limited and poor infrastructural facilities, competing for demand with passenger transportation, poor or weak policy actions, poor management and operational neglect [22]. Moreover, since the independence of Nigeria, the major foc us of infrastructural facilities investment and policy matters relating to transportation sector has been gea red towards passenger movement at the expenses of the freight transportation leading to various economic catastrophes. Meanwhile, infrastructural facilities are undoubted determinants of the competitive success of the sectors of the economy including the agric ultural sector.

In this regard, [10] opines that well-functioning transportation infrastructure is crucial to keep transportation costs at a low level and preserve intemational competitiveness, while a lacking infrastructure may generate high costs for transportation and logistic s as well as lead to congestion and consequently longer delivery time in peak harvest sea sons. Supporting this a ssertion, [9] observes that transportation infra structure can determine the competitive success of a gric ultural enterprises or the entire agricultural sector. With the increasing food crises, extreme weather and failure of infrastructure rated as top world global risks [26], the need to minimize these contemporary global risks, minimize the loss in socio-economic values and ensure efficient delivery of agricultural produce undersc ore workable fra mework for transporting the a gric ultural freight.

"Ref [3]" opined that the importance of good rural-urban roadsand suita ble means of transporting agric ultural produce that encourages high productivity and profitable prices with the minimized cost of transportation is extremely essential. Accordingly, [13] found that different transport networks used for movement and logistic s distribution partic ula rly freighting of a gric ultural produce or commodities a re affected by problems like; instability of ga soline price, delay and ha rassment by law enforcement as factors causing ineffic iency in the distribution of a gricultural commodities a side from others that cause damage, perishing and loss of weight include poor transport infrastructures, numerous driver stopoverplacesand mechanic al problems that are mostly because of old age of vehicles. "Ref [14]" also established that the quality of transport servic es for enterprises and orga nizations of agric ultural and industrial complexes and harvesting-transportation-realization (HTS) complex does not meet contemporary requirements. Accordingly, the increase in transportation cost is directly passed on to the weaker market player that is the failure to meet the contemporary requirements. Thus, rising transportation costs affect market prices. In other words, a study conducted by [27] revealed that time restriction can inc rea se freight costs and slightly dec rease local emissions, while logistic s sprawl can inc rease both costs and emissions.

\section{MATERIALSAND METHODS}

\section{A. Study Area (Saki Area of Oyo State, Nigeria)}

Saki a rea with headquarters in Saki town is one of the ancient Yoruba towns in Nigeria. It is known to be the first settlement founded by Ogun [1] and has a close affinity with Oyo. The area is a prominent agricultural settlement right from the period it was founded in which faming was the second factor that popularized it in the 19th century. Saki area was known as Ifedapo Local Govemment Area with headquarters in Saki till 1996 when it was restructured into Saki East, Saki West and Atisbo Local Govemment Areas.

The study area has an estimated land a rea of $6410 \mathrm{~km}^{2}$ and is located in Oyo North Senatorial District of Oyo State and is geographically located between latitude 8020' and 900' North of the Equator and between longitudes 2040' and 3050' East and West of the Greenwich meridian respectively [6]. The area is endowed with favourable climate and vegetation which pemit the luxuriant growth of grasses and cereal crops. However, road transport is the dominant mode of transport used and the network is characterized by both private and public-private vehicular movements with the absence of conventional public transport system within the study area. 


\section{B. Sampling Collection}

In achieving the goal of this study, combinations of methods are used in sourc ing for the required data from farmers in the study a rea. First, primary data consisted of the use of a questionnaire as a major instrument. This enabled the administration of questionnaires to fa mers as a major sta keholder in evacuation and transportation of a gricultural freight. This was complemented by oral interview and personal observations of related events in the agric ultural freight transportation in the study a rea.

This study centred on the id entified fa rmers' groups in the study a rea na mely Asso cia tion of Fa rmers in Nigeria (AFAN), Farmers Development Union (FADU) and Ifedapo Fa mers Association (IFA) with a total of 9,015 members from which $2.5 \%$ (225) respondents were randomly selected within Sa ki a rea. However, Sa ki area of Oyo sta te which is the study a rea is known as the centre of agric ultural a c tivities in the region considering the degree of agric ultural practice, qua ntity of a gricultural produce, tra ding and transportation in the area.

Secondary Source of data employed the use of published and unpublished related materials. This data source provided a better understanding of nature, evolution and pattern of a gricultural freight in the country at large. However, both descriptive and inferential techniques were used to present and analyze data collected. Descriptively, percentage frequency tables and charts were used to present the obtained data, while the hypothetic al statement ( $\mathrm{H}_{0}$ : there is no significant relationship between attributes of agricultural produce and transport cost) was inferentia lly tested using the multip le regression tec hnique. Inva riably, both the desc riptive statistics (used for data presentation) and the inferential statistics of regression analysis (used for empinical understanding that is to test postulated hypothesis) were run through the use of Statistical Package for Soc ial Sc iences SPSS IBM version 21.
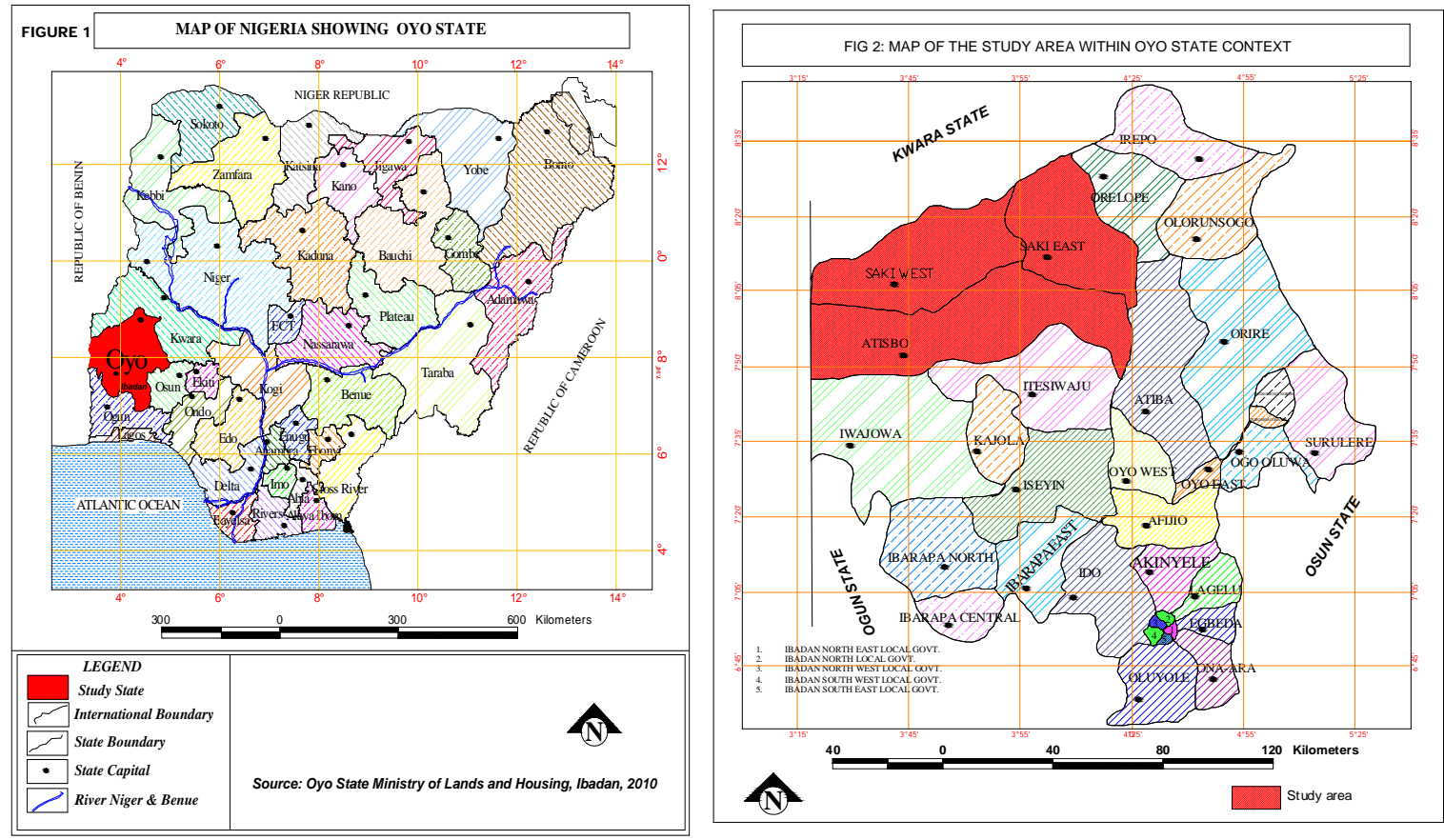
Logistic $s \&$ Susta ina ble Transport

Vol. 11, No. 1, February 2020, 81-89 doi: $10.2478 /$ jlst-2020-0005

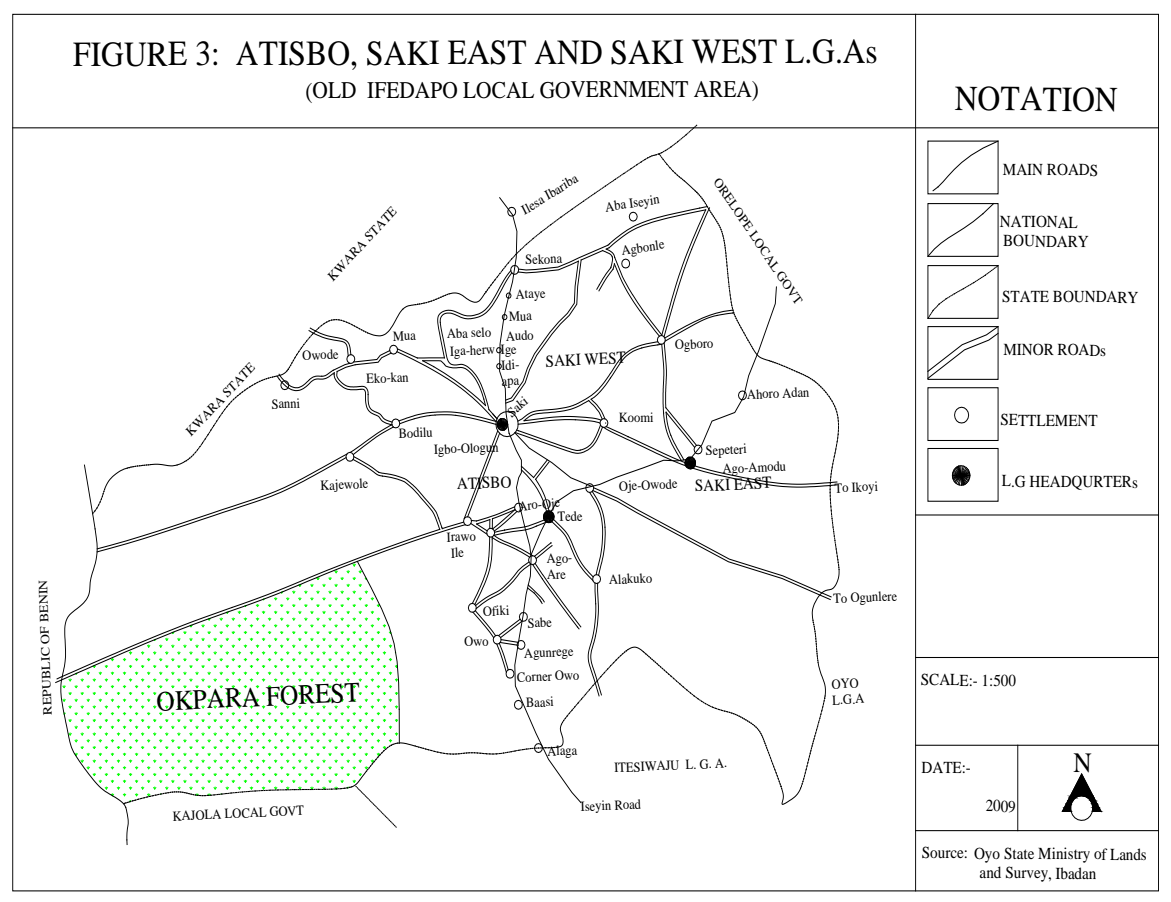

\section{RESULTS AND DISC USSION}

\section{A. Socio-Ec onomic Characteristic s of Respondents (Fa mers)}

The result of the administered questionnaire was summarily presented in this section with supporting Tables and charts. The survey findings revealed in Table 1, shows that, slightly less than three-quarter of famers (72.9\%) were males, while the remaining which is almost one-quarter were females. This is not unusual since male have been dominating agricultural practice and production since time immemorial. Also, the majority of famers have matured age-wise as none of the respondents was below the age of 18 . It was observed that more than one-third of farmers (34.2\%) were $50-59$ years and slightly over one-tenth (12.0\%) were within 18-29years. It can be deduced that none of the respondents could be regarded as a teenager as a significant proportion (of more than three-quarter) are those above 29 years old.

On the educational atta inment of the respondents, the study shows that slightly above a quarter of farmers (26.7\%) possessed primary school certificate, less than a quarter (24.9\%) with secondary school certificate $(24.9 \%)$ and $15.6 \%$ has no formal education. Those with NCE/ND and BSC./HND certific ates accounted for $14.7 \%$ and $11.6 \%$ respectively, while $6.7 \%$ possessed higher degrees. This shows that more than three-quarters of farmers are literate, considering the various classes of academic qualifications they possessed. The manital status of respondents showed that majority (70.2\%) of them were maried, while those who are divorced and separated accounted for $15.1 \%$ and $5.7 \%$ respectively. 
Logistic $s \&$ Susta ina ble Transport

Vol. 11, No. 1, February 2020, 81-89

doi: 10.2478/jlst-2020-0005

Table 1: Socio-Ec onomic Characteristic s of Respondents (Famers)

\begin{tabular}{|c|c|c|c|}
\hline \multicolumn{2}{|l|}{ Variables } & Frequency & $\%$ \\
\hline \multirow[t]{2}{*}{ Sex: } & Male & 164 & 72.9 \\
\hline & Female & 61 & 27.1 \\
\hline \multirow[t]{5}{*}{ Age: } & $18-29$ & 27 & 12.0 \\
\hline & 30-39 & 38 & 16.9 \\
\hline & $40-49$ & 50 & 22.2 \\
\hline & $50-59$ & 77 & 34.2 \\
\hline & 60 and above & 33 & 14.7 \\
\hline \multirow[t]{3}{*}{ Education: } & None & 35 & 15.6 \\
\hline & Primary school & 60 & 26.7 \\
\hline & Secondary & 56 & 24.9 \\
\hline \multicolumn{4}{|l|}{ school } \\
\hline & NCE/ND & 33 & 14.7 \\
\hline & HND/Bsc & 26 & 11.6 \\
\hline & Higher degree & 15 & 6.7 \\
\hline \multicolumn{2}{|c|}{ Marital sta tus: Single } & 21 & 9.3 \\
\hline & Married & 158 & 70.2 \\
\hline & Divorced & 34 & 15.1 \\
\hline & Separated & 12 & 5.3 \\
\hline \multirow[t]{5}{*}{ Inc ome: } & N7,500-N10,000 & 31 & 13.8 \\
\hline & N10,001-N20,000 & 27 & 12.0 \\
\hline & N20,001-N30,000 & 52 & 23.1 \\
\hline & N30,001-N40,000 & 69 & 30.7 \\
\hline & Above $N 40,000$ & 46 & 20.4 \\
\hline
\end{tabular}

Source: Field work, 2018.

The average monthly income of sampled famers ranged from N7,500 to above $N 41,000$. Also, more than one-quarter (30.7\%) rea lized N30,001-N40,000, while slightly lower than a quarter (23.1\%) eamed N20,001-N30,000 on a stream of production. Less than a quarter $(20.4 \%)$ eamed above $\mathrm{N} 41,000$, and the remaining $13.8 \%$ and $12.0 \%$ accounted for those eaming $\mathrm{N7}, 500-\mathrm{N} 10,000$ and N10,001-N20,000 respectively on monthly (Note that Tables and charts are from Authors, 2011 unless stated otherwise).

\section{B. Nature of Farming and Fa m Characteristic s in the Study Area}

Table 2 shows the responses related to the nature of farming and farm characteristics of the sampled farmersin the study area. Conceming the numberand types of fa msowned, it wasobserved that majority of famers cultivated more than one farmland. Precisely, $36.4 \%$ and $36.0 \%$ of famers have two and three numbers of farms respectively, $14.7 \%$ cultivate more than three fams, and the remaining $12.9 \%$ have only one fam. Also, more than one third (38.2\%) of farmers cultivated forest/distant fa ms, more than half ( $52.0 \%$ ) have both neighbourhood and forest farms, while less than one-tenth $(9.8 \%)$ cultivated only neighbourhood farm.

Table 2: Nature of Farm and Farm Characteristic s of Respondents

\begin{tabular}{|c|c|c|c|c|c|}
\hline \multicolumn{3}{|c|}{ Number of farms } & \multicolumn{3}{|c|}{ Types of farms } \\
\hline Number & Frequency & $\%$ & Types & Frequency & $\%$ \\
\hline One & 29 & 12.9 & Neighbourhood & 22 & 9.8 \\
\hline Two & 82 & 36.4 & Forest/distant & 86 & 38.2 \\
\hline Three & 81 & 36.0 & Both & 117 & 52.0 \\
\hline More than three & 33 & 14.7 & Other specify & - & - \\
\hline \multicolumn{3}{|c|}{ Farming experience } & \multicolumn{3}{|c|}{ Farm distance } \\
\hline Experience: $<5 y r s$ & 26 & 11.6 & $1-5 \mathrm{~km}$ & 23 & 10.2 \\
\hline 6-10 years & 37 & 16.4 & $6-10 \mathrm{~km}$ & 38 & 16.9 \\
\hline $11-15$ years & 53 & 23.6 & $11-15 \mathrm{~km}$ & 51 & 22.7 \\
\hline 16-20 years & 86 & 38.2 & $16-20 \mathrm{~km}$ & 62 & 27.6 \\
\hline Above 21 years & 23 & 10.2 & Above $21 \mathrm{~km}$ & 51 & 22.7 \\
\hline
\end{tabular}

Source: Field work, 2018.

Similarly, on the findings of faming experience and fam distance presented in Table 2 , it is observed that more than a quarter (38.2\%) has been fa ming for $16-29$ years, close to a quarter (23.6\%) 
has $11-15$ years of experience, less than one-fifth (16.4\%) has 6-10 years of experience and a bout onetenth $(11.6 \%)$ are those with less than 5 years faming experience. Famers whose experience transcends 21 years account for $10.2 \%$ of the sampled population. With this, famers sampled are professionals, and their views could be seen as reliable and dependable considering the number of years they have been practising fa ming. However, it is equally observed that more than one quarter (27.6\%) of fa mers have theirfarm within the distance of $16-20 \mathrm{~km}$, less than a quarter $(22.7 \%)$ tra velled $11-15 \mathrm{~km}$ to their fa ms, and those whose fa ms distance exceeds $21 \mathrm{~km}$ account for $22.7 \%$, while onetenth $(10.2 \%)$ and less than one-fifth (16.9\%) travelled $1-5 \mathrm{~km}$ and $6-10 \mathrm{~km}$ respectively to their farms daily. With this, the majority of farmers have their fa ms above $5 \mathrm{~km}$ from their homes.

\section{Characterization of Agric ultural Production and Freight Transportation}

Table 3 shows the response of farmers to varieties of issues regarding farm produce and harvest periods. It was observed that the dominant fam produce in Saki area were food crops, tubers, vegetables/fruits and poultry products. However, nearly a quarter of farmers (21.3\%) combined food crops and tuber produce, while less than a quarter (18.7\%) produced tuber only. $14.2 \%$ and $17.3 \%$ accounted for those whose fam produce were food cropsand vegetable/fruits respectively. Fa mers who combined vegetables/fruits and food crops were $12.0 \%$, while poultry produce accounted for $16.4 \%$ of the responses received. It is deduced from this that, combinations of food crops, tubers, poultry, fruits and vegetables dominated the study area of which the cultivation is continued throughout the years.

Similarly, the harvest periods for the crops/produce ranged from 1-3 months to more than 12 months as the case may be. It is observed that nearly half of famers a mounting to $42.2 \%$ have their harvest periods to be $10-12$ months, while less than a quarter (23.6\%) harvests their produce in $7-9$ months. Those whose harvest periods are 4-6 months and $1-3$ months account for $16.0 \%$ and $9.8 \%$ respectively, while the remaining $8.4 \%$ account for those whose harvest period transc end 12 months. It can be deduced that produce harvest in the study area is almost throughout the year as there is always one product or the other to harvest within three months interval.

On the typesand nature of road used by farmers, it is shown that nearly two-thirds of roadslea ding to the farms were single lane-roads which accounted for $74.7 \%$, while the remaining (27.3\%) were footpaths. Also, $76 \%$ of the roads a re earth surfaced roads, while the rema ining (24\%) are bituminous. It can be extracted from the data that most of the famswere accessible by roads irespective of their qua lity and standards. However, the condition of roadsa sassessed by the famers (and a lso observed by the authors) showed that more than half were in deplorable conditions while slightly less than a quarter were fair. Those who stated that the condition of the road in their area was good and very good were very few as represented by their meagre size in the sector. Hence, deplorable conditions of roads have very serious negative effects on the flow of a gricultural freight in the area.

Conceming the movement of produce after harvest, it is observed that close to half of farmers (43.1\%) moved their produce to markets outside their community; while more than a quarter (32.4\%) moved their produce to markets within their community after harvest. Those who moved their harvested produce home were $12.9 \%$, while $11.6 \%$ sold their produce on the farm. Also, on the packaging of fam produce, half of the farmers sampled $(50.7 \%)$ do not package their harvested produce, while slightly higher than a quarter (28.9\%) used the sack as packaging material. Those who use basket accounted for $11.6 \%$, while the remaining $8.9 \%$ used specialized unit such as crate/pallet. This showed that the type of packaging used depends on the type and nature of farm produce to be transported. However, bags were used to package food crops such as yam flour, beans, cowpea and maize among others while tubers such as yam required no packaging. Likewise, poultry products such as eggs and chicken used a crate and specialized container (box) as packaging material for safety reasons and to maintain the market values.

Of the five means used by farmers in transporting fam produce to markets in the study a rea, the use of taxi/car ranked highest as it accounted for $41.8 \%$ of the means used. This is followed by motorcycle (17.8\%), truck/lomy (16.9\%), human porterage (9.3\%) and the use of bus (14.2\%). This shows 
Logistic $s \&$ Susta ina ble Transport

Vol. 11, No. 1, February 2020, 81-89

doi: $10.2478 /$ jlst-2020-0005

that human porterage is steadily fading away as the dominant means of transporting produce, especially over a long distance, while the use of taxi/car is gaining prominence. Also, the use of taxi/car is more rampant for transporting produce to markets within the community/area, while truck/lomy dominated those uses for markets outside the community because of their large camyingcapacity and long distance involved. Simila rly, it wa s observed that $36.0 \%$ of fa mers each attributed the reason for mode selection to the availability of specific vehicles, and volume of freight to be moved. Also, $14.7 \%$ and $13.3 \%$ attributed their rea sons to be cheapness and affordability respectively which were the ma in factors of patronizing a particular mode fortransporting the produce. However, both the volume of production and the availability of typical transport means are the dominant factors that influenced farmers in their modal selection for freight movement in the area.

It is observed in Table 4 that famers relied on both retailers and wholesalers for the marketing of their produce. By this, only a quarter of famers (25.4\%) market their produce directly, while those who market their products through retailers and wholesalers accounted for $37.3 \%$ each of the sampled famers. Also, a significant proportion of famers (52.4\%) patronizes markets periodic ally in the study area, $19.1 \%$ each represented those who visited markets weekly and occasionally, while the remaining minority $9.3 \%$ patronize market on daily basis. With this, it deduced that most famers patronized markets periodic ally in the area since marketing day is fixed / scheduled for buyers and sellers to converge for transactions.

On the trip distance and duration, it is observed that more than one-quarter of farmers (38.2\%) made a trip that exceeded $200 \mathrm{~km}$, while those with less than $50 \mathrm{~km}$ account for $19.6 \%$. Also, $16.9 \%$ of fa mers cover $151-200 \mathrm{~km}$, while those who cover $101-150 \mathrm{~km}$ a mounted to $10.7 \%$ and the remaining $14.7 \%$ are those whose trip distance is $51-100 \mathrm{~km}$. The trip duration of famers in the study area ranges between less than 60 minutes and above 4 hours. A slightly higher than a quarter (29.3\%) has a trip duration of $181-240$ minutes, while $20.4 \%$ and $20.0 \%$ of them ha ve trip durations of $121-180$ minutes and 61-120 minutes respectively. The remaining $18.2 \%$ account for those with a trip duration that exceed 4 hours. It is deduced from the data that trip distance and time spent in travelling to markets is higher considering the geographical location of the study a rea to other possible urban markets.

Table 3: Characterization of Agricultural Production and Freight Movement

\begin{tabular}{|c|c|c|c|c|c|}
\hline \multicolumn{3}{|c|}{ Agric ultural Produce } & \multicolumn{3}{|c|}{ Harvesting periods } \\
\hline Varieties & Frequency & $\%$ & Periods & $\begin{array}{c}\text { Frequen } \\
\text { cy }\end{array}$ & $\%$ \\
\hline Food crops & 32 & 14.2 & 1-3months & 22 & 9.8 \\
\hline Tubers & 42 & 18.7 & 4-6months & 36 & 16.0 \\
\hline Fruits & 39 & 17.3 & 7-9months & 53 & 23.6 \\
\hline Poultry & 37 & 16.4 & 10-12months & 95 & 42.2 \\
\hline Food crops/tubers & 48 & 21.3 & Above 12 months & 19 & 9.4 \\
\hline Vegetables/crops & 27 & 12.0 & Other specify & - & - \\
\hline \multicolumn{3}{|c|}{ Types of road } & \multicolumn{3}{|c|}{ Nature of road surfacing } \\
\hline Footpath & 57 & 25.3 & Bitumino us surfa cing & 54 & 24.0 \\
\hline Single la ne & 168 & 74.7 & Earth-road & 171 & 76.0 \\
\hline \multicolumn{3}{|c|}{ Pattem of freight movement } & \multicolumn{3}{|c|}{ Freight packaging } \\
\hline Movement: To home & 29 & 12.9 & Packaging: None & 114 & 50.7 \\
\hline Within markets & 73 & 32.4 & Sack & 65 & 28.9 \\
\hline Outside markets & 97 & 43.1 & Ba skets & 26 & 11.6 \\
\hline Sold at point of harvest & 97 & 11.6 & Crate/box & 20 & 8.9 \\
\hline \multicolumn{3}{|c|}{ Means of freight movement } & \multicolumn{3}{|c|}{ Factors for transport selection } \\
\hline Human porterage & 21 & 9.3 & Ava ilability & 81 & 36.0 \\
\hline Motorcycle & 40 & 17.8 & Cheapness & 33 & 14.7 \\
\hline Bus & 32 & 14.2 & Affordability & 30 & 13.3 \\
\hline Taxi/car & 94 & 41.8 & Produce volume & 81 & 36.0 \\
\hline Truck/Lomy & 38 & 16.9 & Other specify & - & - \\
\hline \multicolumn{3}{|c|}{ Methods of produce marketing } & \multicolumn{3}{|c|}{ Rate of market patronage by farmers } \\
\hline Self-marketing & 57 & 25,4 & Daily & 21 & 9.3 \\
\hline Retailers & 84 & 37.3 & Weekly & 43 & 19.1 \\
\hline Wholesalers & 84 & 37.3 & Periodically & 118 & 52.4 \\
\hline Other specify & - & - & Occasionally & 43 & 19.1 \\
\hline \multicolumn{3}{|c|}{ Trip Durations of fa mers } & \multicolumn{3}{|c|}{ Average distance Traveled } \\
\hline Less than $50 \mathrm{~km}$ & 44 & 19.6 & Less than 60mins & 27 & 12.0 \\
\hline
\end{tabular}


Logistic s \& Susta ina ble Transport

Vol. 11, No. 1, February 2020, 81-89

doi: $10.2478 /$ jlst-2020-0005

\begin{tabular}{|c|c|c|c|c|c|}
\hline & & & & & \\
\hline 51-100km & 33 & 14.7 & 61-120mins & 45 & 20.0 \\
\hline 101-150km & 24 & 10.7 & 121-180mins & 46 & 20.4 \\
\hline 151-200km & 38 & 16.9 & 181-240mins & 66 & 29.3 \\
\hline Above $200 \mathrm{~km}$ & 86 & 38.2 & Above 4hours & 41 & 18.2 \\
\hline \multicolumn{3}{|c|}{ Inc ome realized } & \multicolumn{3}{|c|}{ Implic a tions of exorbitant transport cost } \\
\hline Less than N5,000 & 17 & 7.6 & Increased selling price & 29 & 12.9 \\
\hline N5,001-N10,000 & 28 & 12.4 & cost of production & 80 & 35.6 \\
\hline N10,001-N15,000 & 33 & 14.7 & Reduction in profit & 116 & 51.5 \\
\hline N15,001-N20,000 & 59 & 26.2 & Other specify & - & - \\
\hline N20,001-N25,000 & 30 & 13.3 & - & - & - \\
\hline Above N25,001 & 58 & 25.8 & - & - & - \\
\hline \multicolumn{3}{|c|}{ Problems encountered } & \multicolumn{3}{|c|}{ Fa mers' suggestions for improvement } \\
\hline High tra nsport fare & 66 & 29.3 & Road rehabilitation & 90 & 40.0 \\
\hline Road extortion & 49 & 21.8 & Grant provision & 34 & 17.3 \\
\hline Deplorable roads & 89 & 39.6 & Extortion minimization & 44 & 19.6 \\
\hline Road insec unity & 21 & 9.3 & Road secunity & 26 & 11.6 \\
\hline Road accident & - & - & Rail service & 26 & 11.6 \\
\hline Other specify & - & - & Other specify & - & - \\
\hline
\end{tabular}

Source: Field work, 2018.

Also, three implic ations of exorbitant tra nsport costs on agric ultural produce in the study a rea were identified and presented in Table 3. Findings revealed that over half of the respondents (51.5\%) expressed obvious reduction in the profit accrued to them at the end of the farming year, more than quarter (35.6\%) identify inc essa nt inc rement in the cost of fa m production due to outra geoustra nsport cost, while it increased the selling price of the agricultural produce $(12.9 \%)$ in the markets, hence reducing selling rate and increasing rate of leftovers. From the foregoing, one major inference dra wn is that there is a steady reduction in the quantity of agric ultural produce being sold daily due to high market prices attached to such, and subsequent reduction in antic ipated profits.

The problemsencountered by famers in the course of transporting agric ultural freight in the study area show that deplorable road condition (39.6\%), high transport fare (29.3\%) and road extortions (21.8\%). Also, $9.3 \%$ of famers identify a high rate of route insecurity for freight transportation in the area. Considering the responses above, it is clear that challenges facing agricultural freight transportation in the study a rea are multi-faceted to the extent that the challenges equally slowing down the distribution and supplying process of agric ultural freight in the area. In contrast, famers made useful suggestions towards improving the existing situation as more than a quarter of famers $(40.0 \%)$ identify extensive road habilitation, less than one fifth (17.3\%) recommend the provision of suitable vehic les by govemment and $19.6 \%$ identify minimization of road extortion. Lastly, $11.6 \%$ each identify improved road sec unity and extensive rail network/service to the a rea.

\section{Results of Hypothesis Testing}

Further investigations were ca mied out to establish the degree of affinity between the dependent (transp orta tion cost) and independent varia bles (attrib utes of a gric ultural freight) a nd were exa mined through the use of multiple regression analysis. This a nalytical tec hnique makesuse of dummy va ria ble of the regression model to calibrate some of the qualitative predictor variables to quantitative va riables in a dic hotomous form, while other predic tors and dependent variable (transportation cost) were measured on a continuous scale. However, Table 4 combined the major output of multiple regression results that includes the model summary, the analysis of variance table of the test of signific ance of the model, and more importantly the unstandardized coeffic ient as well as the T-values and their signific ance values. The multiple regression coeffic ients, partic ula rly the $R 2$ is 0.481 , reflecting that $48 \%$ of the variation in transportation cost is expla ined by the independent variables combine (predic tors). This level of explanation hasan a nalysis of varia nce of the model of $F$ ratio value of 11.916, which is statistic ally signific ant at 0.000 (Table 4). However, the independent variables (predictors) combined to expla in signific antly the transportation cost incurred by respondents for the movement of their a gric ultural freight.

In other words, in terms of the relative importance of the individual predictors in the model used, thirteen (13) out of the nineteen (19) predic ting varia bles a re statistic ally signific a nt, na mely: diffic ulty encountered ( $p=0.000)$, farm harvest period $(p=0.002)$, famland size (hectare) $(p=0.000)$, nature of 
Logistic $s \&$ Susta ina ble Transport

Vol. 11, No. 1, February 2020, 81-89

doi: $10.2478 /$ jlst-2020-0005

road ( $p=0.16)$, volume of fa m produce $(p=0.000)$, a verage fa m distance $(p=0.011)$, transport means to farm $(p=0.038)$, fam type(s) $(p=0.002)$, trip distance $(p=0.000)$, produce transport to market $(p=0.037)$, rate of market patronage $(p=0.029)$, road condition $(p=0.000)$, trip duration $(p=0.002)$. Perhaps these variable are the most important of the statistically signific ant predic tors. With decision rule that $\mathrm{H}_{0}$ should be accepted if calculated $\mathrm{p}$. value is more than 0.05 significance level, it is observed from Table 4, that the calculated p.value $(0.000)$ is less than 0.05 significant level (Table 4). Hence, the $H_{1}$ is accepted while the $H_{0}$ is rejected. However, it is observed that the attributes of agricultural freight are statistic ally influenced by transportation cost. Hence, the cost of agricultural freight production is a function of transport cost.

Table 4: Regression Result ( $\mathrm{H}_{0}$ : There is no Signific ant Relationship between Attributes of Agric ultural Produce and Transport Cost)

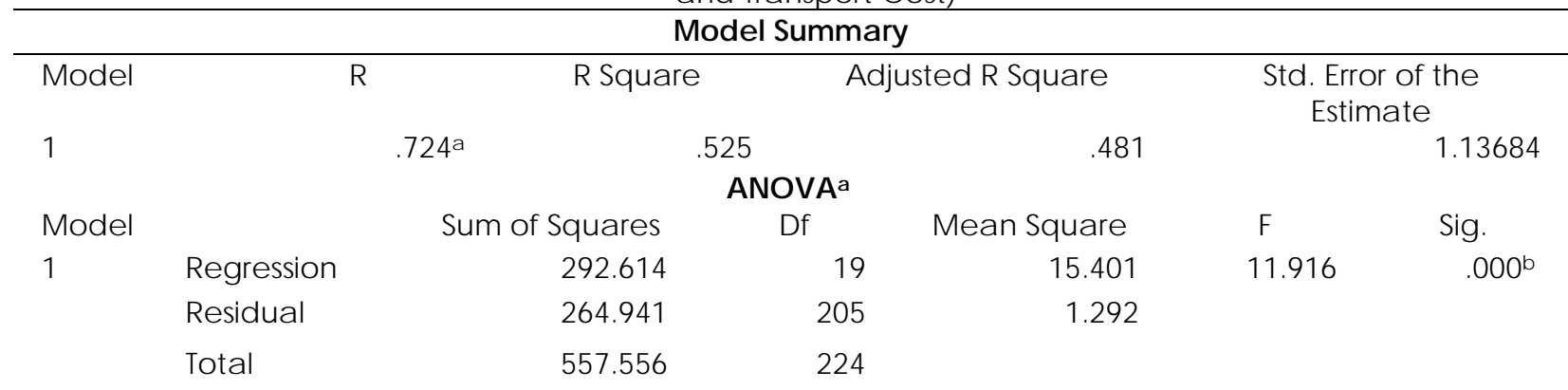

a. Dependent Variable: TRANSPORTCOST

b. Predictors: (Constant), Diffic ulty Encountered, Farm Harvest Period, Number of Fa ms, Fa mland Size (Hectare), Nature of Road, Farm Produce, Average Farm Distance, Transport Means to Farm, Packaging Required, Type of Road to Fa m, Farm Type(S), Produce Movement After Harvest, Farm Produce Marketing, Trip Distance, Produce Transport to Market, Rate of Market Patronage, Road Condition, Inc ome Realizable, Trip Duration

Model

1

(Constant)

Number Of Farms

Farm Type(S)

Average Farm Distance

Transport Means To

Farm

Farmland Size (Hectare)

Volume Farm Produce

Farm Harvest Period

Nature Of Road

Type Of Road To Farm

Road Condition

Produce Movement

After Ha rvest

Packaging Required

Farm Produce

Marketing

Produce Transport To

Market

Rate Of Market

Patronage

Trip Distance

Trip Duration

Income Rea lizable

Diffic ulty Encountered

\section{Coefficientsa}

Unstanda rdized Coeffic ients

B

$-1.002$

$-.082$

.508

.263

.145

.542

$-.059$

$-.293$

.329

.194

.498

.030

Std. Error

.896

.112

.158

.103

.083

.091

.056

.106

.234

.212

.119

.115

.044

.010

$-.132$

.240

$-.296$

$-.341$

$-.049$

.459

.154

.068

.082

.114

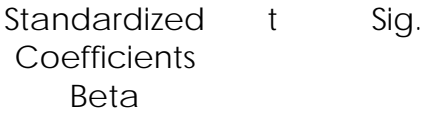

Beta

\begin{tabular}{r}
-.046 \\
.214 \\
.213 \\
.101 \\
\\
.382 \\
-.061 \\
-.208 \\
.089 \\
.054 \\
.324 \\
.016 \\
.027 \\
.005 \\
-.152 \\
.129 \\
\hline .296 \\
-.279 \\
-.049 \\
.289
\end{tabular}

$-1.119$

$-.731$

3.213

2.560

1.744

5.937

$-1.047$

$-2.753$

1.408

.916

4.186

.256

.477

.064

$-2.097$

.037

1.658

.029

$-4.326$

.000

$-3.110$

.002 
Logistic $s \&$ Susta ina ble Transport

Vol. 11, No. 1, February 2020, 81-89

doi: $10.2478 /$ jlst-2020-0005

\section{E. State of Agric ultural Freight Transportation in Oyo State}

On the outc ome of the in-depth Interview with relevant govemment Ministries, Department and Agencies(MDAs) such as the Oyo Sta te Ministry of Agric ulture and Natural Resources, Ministry of Works and Tra nsport, Oyo Sta te Agric ultura I Development Progra mme (OYSADEP), Department of Worksand Agriculture, the findings showed that there was no designated govemment intervention on a gric ultural freight in the study area. Rather, what c ould be seen as interventions relating to the scope of this study were agric ultural development initiatives caried out by OYSADEP. The programme was specifically established to stimulate efficient agricultural production by transfer of adaptable technologies in all areas of agricultural practice towards increasing famers' productivity, income generation and standard of living [7, 17]. OSADEP was also strengthened in finance, research, personnel and empowered to rehabilitate rural-farm roads equipment as well as very active and reso urc eful during the period to fa mers and the communities. However, the relocation of operational headquarters of OYSADEP to Ibadan and her gross underfunding incapacitated the Agency in proceeding with its mandate especially, as related to rural farm roads. Further, rural roads and rural transp ort infrastructure in the study a rea were attended to through the defunct Directorate of Foods, Roads and Rural Infrastructure (DFRRI) as Saki-Ogboro-lgboho and Igboho-lgbeti roads were resurfaced and upgraded during DIFRRI era $[6,7,17]$.

\section{CONCLUSION AND RECOMMENDATIONS}

This paper had assessed agricultural freight transportation in Saki Area of Oyo State towards improving the economy of the study area through the strengthening of mechanism for evacuation, movement and transportation agricultural produce and freights which will greatly minimize hunger and malnutrition attributed to the ineffic ient supply of farm produce especially to urban populace. The study reiterated the importance of good roads and suitable means of transporting agricultural freight and farm produce to encourage productivity and enhancing profitable prices while minimizing the cost of transportation that reduces famers' yield and profits. It was established that food crops, vegetables, fruits and poultry products abound in commercial quantity in Saki area as faming and produce trading occur throughout the year. Agricultural freight transportation is often a neglected issue that usua lly has signific ant consequences on the access to cheap and affordable farm products by urban residents and by extension health and well-being.

With Saki area being the remotest part of Oyo state from lbadan, the state capital, famers face immense constraints before their agricultural produce could be evacuated, and transported to various urban markets spread a cross the country and beyond due to deplorable conditions of roads and associated challenges with such exercise. This usually brings about an economic loss in the famers' output especially when involved with the perishables and by extension, reduce the socioeconomic potentials of famers involved. While the issues of agricultural freight transportation transcend road improvement, the study concludes that there is total neglect of agricultural freight transport in the study area in particular, and the country at large. This is attested to by the Oyo State Govemment's $10 \mathrm{~km}$ policy of road rehabilitation that was only restricted to urban centres in which rural roads a re excluded from such scheme.

With this, local roads in the Oke-Ogun area of Oyo State, in partic ular, are in extremely deplorable conditions as the earth-roads are ra rely ma inta ined. Therefore, the assessments of a gric ultural freight transportation in the study a rea revealed characteristics that reflect depletion in energy, declining profit and high running costs for famers. It is on the base of the above that, the following recommendations are made. First is the provision for agricultural produce databank and storage facility to have a susta inable plan and effic ient mecha nism fora gric ultural freight transportation in the study a rea and the country. By this, the govemment should make provision fora storage facility in Sa ki where accurate measurement and records of products shall be taken for planning purposes. This, in tum, will undoubtedly make Saki as one of the major hubs for agric ultural freights that will enable an a dequate record of data and fam produce to be kept forfuture use and a nalysis home and abroad. The re-introduction of a storage system with an emphasis on small-scale and large scale depot is capable of promoting sustainable agricultural freight transportation. 
Second, extensive road rehabilitation and construction in the study a rea is another issue that has to be addressed. The importance of a good road system in terms of design, construction and regular maintenance to the general development of any economy is enomous. In view of this, concerted efforts by govemment at all levels to strategize towards improving the quality and performance of roads in agricultural producing a reas like Saki is essential. Adequate initiation and funding of rural roads as well as their routine maintenance by specialized agencies such as Federal Roads Maintenance Agency and Oyo State Road Maintenance Agency are veritable to improving the quality of rural lives and rural economy.

The traditional role of OYSADEP in the overall development of agricultural production and improving rural infrastructure in Oyo state should be restored by Oyo State govemment. Thus, the a gency should be re-organised and empowered with her operational hea dquarters retumed to Saki. This shall greatly facilitate her complementary role of improving and maintaining rural access roads for easy evacuation and transportation of a gricultural produce from farms to the storage facility and by extension, markets.

The preparation and implementation of Saki Regional Development Plan and transport plan are long overdue. These plans shall hamess the resources and potentials that abound in the agricultural sector in Saki area in particular and Oke-Ogun area as a whole for the overall development of Oyo state and the country at large. It is of note that the plan shall integrate land uses, population, critical infrastructure and human capital resources in the area towards strengthening the economy of the region among others. The resources of the area could be better utilized as Regional Development Plan shall ensure that settlements and villages were not only planned according to the natural endowment but also integrated into the national economy.

\section{REFERENCES}

1. Adebisi, J. A. (1986). Resources Development as Strategy for Rural Development in Ifeda po Local Govemment Area of Oyo State, Unpublished HND project, The Polytechnic, Ibadan, Nigeria, pp 20.

2. Ademiluyi, I. A. (2006). Historical evolutions and characteristics of transport modes in Nigeria. Babcock Joumal of Management and Social Sciences, Vol. 5 No 1, pp. 91-109.

3. Afolabi, O.J., Ademiluyi, I. A. and Oyetubi, A. O. (2016). Analysis of rural tra nsporta tion of agricultural produce in ljebu North Local Govemment area Ogun State Nigeria. Transport \& Logistics: the Intemational J oumal, Vol. 16 No 41, pp. 36-47.

4. Ajiboye, A.O. \& Afolayan, O. (2009). The impact of transportation on agricultural production in a developing country: a case study of kola nut production in Nigeria. Intema tional J oumal of Agric ultural Ec onomic sand Rural Development, Vol. 2 No 2, pp. 49-57.

5. Akanmu, A. A. (2008). Trends and Challenges of Parcel Delivery Service in Nigeria, Postgraduate Diploma Project, Center for Transport Studies, Olabisi Onabanjo University, Ago-Iwoye, Ogun State.

6. Akanmu, A. A. (2013). Appraisal of Agric ultural Freights Transportation in Saki Area of Oyo State, Unpublished M.Sc. dissertation, Olabisi Onabanjo University, Ago-Iwoye, Nigeria.

7. Akanmu, A. A., Ogunsesan, D. K. \& Ogunsesan, A. S. (2013). Development and patronage of parcel delivery service in Nigeria; Challenges and Prospects. The Joumal of Social Sciences and Development, Vol. 1 No 4, pp. 148-160.

8. Balm, S., Browne, M., Leonardi, J., \& Quak, H. (2014). Developing an evaluation framework for an innovative urban and interurban freight transport solution. Procd. Soc. Behv., Vol. 125, pp. 386-397.

9. Caixeta-Filho, J. V. (2013). Transportation and logistics in Brazilian agriculture, Delivered at the Agric ultural Outlook Forum, February 20, 2013

10. Fliehr, O. (2013). Analysis of transportation and logistics processes for soybeans in Brazil. A case study of selected production regions. Thünen Institute of Fam Economics, Working paper 4.

11. Mahmoudifard, S. M. (2016). Travel beha viour a na lysis of a gric ultural commodities in a freight ac tivity mic rosimula tion framework, Unpublished PhD Thesis, the University of Illinois at Chic ago.

12. Mijinyawa, Y. \& Adetunji, J. (2005). Evaluation of fam transportation system in Osun and Oyo States of Nigeria. Agricultural Engineering Intemational: The CIGRE J oumal, Vol. 7 No 5, pp.1-10.

13. Musa, I. J., Abbas, S. and Umar, A. (2014). Logistics and distribution problems of a gric ultural commodities from greater Zaria Area, Nigeria. European J oumal of Business and Management, Vol. 6 No 34, pp. 193-196.

14. Napkhonenko, N., Zagimiak, D. \& Karaeva, M. (2018). Agric ultural cargo transporta tion logistic system development. Intemational J oumal of Engineering \& Technology, Vol. 7 No $4 \& 3$, pp.185-190.

15. Nathanail, E., Mitropoulos, L., Kara kikes, I., \& Adamos G. (2018). Sustainability framework for assessing urban freight transportation measures. Logistics \& Susta inable Development, Vol. 9 No 2, pp. 16-36.

16. Nathanial, E., \& Papoutsis, K. (2013). Towards a sustainable urban freight transport and urban distribution. J oumal of Traffic and Logistic Engineering, Vol. 1 No 1, pp. 58-63. 
Logistic $s \&$ Susta ina ble Transport

Vol. 11, No. 1, February 2020, 81-89

doi: $10.2478 /$ jlst-2020-0005

17. National Fadama Development NFD (2011). Third National Development Project information for Oyo State, online version accessed at www.faddama.net/html/state details.php

18. Ojekunle, J. A. (2004). Urban Freight Transport In A. A. Chiloko, I., Ogunsanya, and A. G. Suma ila, (Eds.). Perspectives on Urban Transportation in Nigeria. Nigerian Institute of Transport Technology, Zaria, pp. 224-241.

19. Okuneye, P. A. (2001): The rising cost of food price and food insecurity in Nigeria and its implication for poverty reduction. Central Bank of Nigeria Economic and Financial Review, Vol. 39 No 4, pp. 88-102.

20. Omole, F. K. \& Owoeye, J. O. (2007). Inter-market transportation and patronage in Osun State, Nigeria. Intemational J oumal of Transportation Studies, Vol. 3 No 1, pp. 57-67.

21. Rodrigue, J. P., Comtos, C. \& Black, B. (2006). The Geography of Transport Systems, 3rd edition, Routledge, New York.

22. Salisu, U.O. (2019). State of transp ort a dministrative structure in La gos, O gun, and Oyo States, Nigeria. J oumal of Spa tial and Organizational Dynamics J SOD, Vol. 7 No 1, pp. 68-85.

23. Sanusi, L. S. (2010). Growth Prospects for the Nigerian Economy, Convocation Lecture Delivered at the Igbinedion University Eighth Convocation Ceremony, Okada, Edo State, November 26, 2010.

24. Soludo, C. C. (2007). Nigerian Economy: Can We Achieve The Vision 20: 2020. Central Bank of Nigeria, Abuja, 8th J anuary 2007.

25. Taiwo, K. A. (2009). The Global Food Crisis and the African Women Famers in proceedings of 3rd Intemational Conference of West Afric an Society of Agric ultural Engineers and 9th Intemational Conference of Nigerian Institute of Agric ultural Engineers held sat Obafemi Awolowo University, lle-lfe, Nigeria on J a nuary 25-29, pg. 307-318.

26. World Economic Forum (2015). G lobal Risks 2015, online version accessed at http://www.weforum.org/risks; accessed $1 / 12 / 20195$.

27. Zhao, B., Zhang, J. \& Wei, W. (2019). Impact of time restriction and logistic s sprawl on urban freight and environment: the case of Beijing a gric ultural freight. Susta ina bility, Vol. 11, pp. 3675- 3691.

\section{AUTHORS}

A. Simeon Oluwagbenga FASINA is with Olabisi Onabanjo University/Department of Urban and Regional Planning, Ago-lwoye, Nigeria

B. Ayobami Ademola AKANMU is with The Oke-Ogun Polytechnic/Department of Urban and Regional Planning, Saki, Nigeria.

C. Adesoji O. ADESANYA is with Nigerian Institute of Social and Economic Research/Policy Engagement Division, lbadan, Nigeria.

D. Umar Obafemi SAUSU is with Olabisi Onabanjo University/Department of Urban and Regional Planning, Ago-Iwoye, Nigeria.

Published as submitted by the author(s). 